\title{
НАЦІОНАЛЬНІ ТА МІЖНАРОДНО-ПРАВОВІ СТАНДАРТИ БОРОТЬБИ 3 КАТУВАННЯМ
}

\author{
САДУЛА Л.М. - кандидат економічних наук, доценТ, юридичний факультет \\ Свропейського університету \\ МЕЛЕШКО О.М. - студент магістратури, юридичний факультет \\ Свропейського університету \\ університету \\ ЛОБУР О.М. - студент магістратури, юридичний факультет Свропейського
}

DOI 10.32782/LAW.UA.2021.4.12

У статті розглядаються питання щодо національних та міжнародно-правових стандартів боротьби з катуванням. Констатовано, що заборона катування, нелюдсъкого $і$ такого, що принижує гідність, поводження $i$ покарання, виступає імперативною нормою міжнародного права, яка імплементована у національне законодавство та відображає одні із ключових изнностей правової та демократичної держави.

Катуванням заподіюється людині ббізичне та (або) моральне страждання. Очевидно, що психічні страждання пов'язані з розладами психіки, а тому така особа потребує спещзалізованого лікування. 3 огляду на ие видається більи правильно говорити про моральні страждання, які власне полягають у пережитих почуттях зневаги, приниження, відчуття власной неповноцінності тощо. У той же час не можна виключати випадків, коли катуванням спричиняються психічні страждання. Такі випадки повинні враховуватись судом як тяжкі наслідки завдані злочином, а саме як обставина, що обтяжує покарання. Питання боротьби із проявами катування перебувають під посиленою увагою міжнародних організачій та водночас потребують належної законодавчої регламентаиї.

Ключові слова: катування, права людини, міжнародно-правові стандарти захисту прав людини, застосування практики Европейсъкого суду з прав людини.

Постановка проблеми

Заборона катування, нелюдського і такого, що принижує гідність, поводження i покарання, виступає імперативною нормою міжнародного права, яка імплементована у національне законодавство та відображає одні із ключових цінностей правової та демократичної держави. Зазначена заборона закріплена чи не у всіх ключових міжнародних документах (Конвенція про захист прав людини та основоположних свобод (ст. 3), Конвенція проти катувань та інших жорстоких, нелюдських або таких, що принижують гідність видів поводження і покарання(ст. 2), Звід принципів захисту всіх осіб, що підлягають затриманню, затвердженого резолюцією Генеральної Асамблеї ООН 1988 p., Міжнародний пакт про громадянські та політичні права 1966 р. (ст. 7), Женевська конвенція про захист цивільного населення під час війни від 12 серпня 1949 (ст. 3) та $\varepsilon$ абсолютною за своїм характером і не підлягає жодним обмеженням чи виняткам. Ні суспільна небезпека, яка загрожує життю нації, ні винятково складні випадки боротьби з організованою злочинністю чи тероризмом, ні будь-які інші обставини не можуть слугувати підставами для відступу [1, с.6]. Окрім того, у національному законодавстві України передбачена кримінально-правова заборона катування (ст.127 КК України).

Не випадково А.I. Скрекля звертає увагу на те, що питання кримінальної відповідальності за жорстоке поводження, у тому числі і за катування, належить до тих, які постають не тільки перед працівниками органів кримінальної юстиції, але й привертають значну увагу науковців. Більше того, узагальнення практики правозастосовних 
органів свідчить про те, що вони стикаються 3 певними труднощами щодо застосування норм про кримінальну відповідальність за суспільно небезпечні діяння, які вчиняються за наявності ознаки жорстокості. На думку цієї вченої, такий стан речей зумовлений низкою факторів, до числа яких відносяться недоліки в конструюванні правових норм, а також відсутності єдності у наукових рекомендаціях [2, с.13]. 3 таким твердженням не можна не погодитись, оскільки нерідко різна кваліфікація одних і тих же кримінальнопротиправних дій зумовлена саме недосконалою редакцією диспозиції статті. Окрім цього, до вказаної проблеми додається ще й невизначеність науковців у питаннях застосування тієї чи іншої норми. А тому розгляд питання в частині міжнародних та національних стандартів боротьби з катуванням є актуальним і затребуваним.

\section{Стан теоретичного дослідження}

Питання кримінальної відповідальності за катування нерідко були предметом розгляду у юридичній літературі. Така пристальна увага до цієї проблематики зумовлена, передусім тим, що одним із пріоритетних напрямків загальної політики у правовій сфері є власне заборона жорстокого поводження з особою, що узгоджується із положеннями п.28 Конституції України та нормами міжнародного права. Окремі аспекти цього питання розглядались у працях О.Ф. Бантишева, М.Г. Гребенюка, М.П. Короленка, В.I. Кучера, В.О. Навроцького, А.І. Скреклі, Ю.О.Поліщука, П.П. Сердюка, Н.М. Ярмиш та інших. Внесок цих науковців у розвиток питань кримінально-правової протидії катуванню важко переоцінити. У той же час попри пильний інтерес науковців до цієї проблематики все ж чимало питань залишаються дискусійними, зокрема, щодо співвідношення понять «моральне» та «психічне» страждання, щодо доцільності одночасного використання у диспозиції ч.1 ст.127 КК України юридичних конструкцій «фізичний біль» та «фізичне страждання» тощо.

3 огляду на це метою статті є вивчення національних та міжнародних стандартів боротьби з катуванням.

\section{Виклад основних положень}

У Конвенції проти катувань та інших жорстоких, нелюдських або таких, що принижують гідність видів поводження і покарання 1984p., поняття «катування» розглядається як будь-яка дія, якою будь-якій особі навмисне заподіюються сильний біль або страждання, фізичне чи моральне, щоб отримати від неї або від третьої особи відомості чи визнання, покарати іiі за дії, які вчинила вона або третя особа чи у вчиненні яких вона підозрюється, а також залякати чи примусити іiі або третю особу, чи з будьякої причини, що грунтується на дискримінації будь-якого виду, коли такий біль або страждання заподіюються державними посадовими особами чи іншими особами, які виступають як офіційні, чи з іх підбурювання, чи з їх відома, чи за їх мовчазної згоди. При цьому в це поняття не включаються біль або страждання, що виникли внаслідок лише законних санкцій, невіддільні від цих санкцій чи спричиняються ними випадково [3]. Дещо близьке за змістом визначення поняття «катування» передбачено у рішенні Европейського суду з прав людини (Ірландія проти Сполученого Королівства), під яких слід розуміти навмисно нелюдське поводження, що викликає досить серйозні і жорстокі страждання. Втім визначення поняття катування не можна вважати досконалим, оскільки навряд чи можна відрізнити поняття сильного болю і фізичного страждання або ж яка межа між поняттям серйозних страждань та жорстоких страждань. А тому Е.Сванідзе цілком слушно зауважує, що відповідь на питання, яке поводження є жорстоким, базується на основі здорового глузду, внаслідок якого пересічний громадянин повинен побачити у певних діях катування або ж припустити, що певне поводження є нелюдським, а відтак - недопустимим та таким, що суперечить загальнолюдським цінностям [4, с.8].

При цьому варто зазначити, що відхід від принципу заборони катування, жорстокого, нелюдського або такого, що принижує гідність, поводження чи покарання є недопустимим. Не випадково Европейський суд 3 прав людини акцентує увагу на тому, що не може бути жодних винятків навіть 


\section{Кримінальне право, кримінальний процес та криміналістика}

за наявності найбільш скрутних обставин, якими власне виступає боротьба проти організованого тероризму або злочинності чи за наявності суспільної небезпеки, яка ставить під загрозу життя нації [5]. Найбільш яскравим прикладом у цій ситуації слугує справа Tomasi v. France, у якій ЕСП в визнав порушення ст.3 Конвенції проти катувань та інших жорстоких, нелюдських або таких, що принижують гідність видів поводження i покарання 1984 р., оскільки під час тримання під вартою заявника, щодо нього застосовувалось жорстоке поводження. У той же час уряд Франції намагався обгрунтувати наявність так званих пом'якшуючих обставин, зокрема того, що заявник вчиняв тяжкі злочини, підозрювався у вбивстві поліцейського та був терористом (член незаконної організації «Корсиканський національний фронт визволення»). Втім Суд не прийняв до уваги такі обставини 3 огляду на те, що боротьба з тероризмом не може виправдати дії посадовців, які завдають фізичних та моральних страждань особі, оскільки це суперечить праву на особисту недоторканність [6]. Така позиція суду є безапеляційною. Уявімо ситуацію, що в окремих чітко визначених випадках (скажімо, врятувати життя викраденої людини чи запобігти вчиненню терористичному акту), можливе застосування катування чи іншого нелюдського поводження 3 метою отримати інформацію від допитуваної особи, яка підозрюється у вчиненні відповідного злочину. Здавалось би, що шкода здоров'ю, яка спричинена такій особі, не є рівноцінною із тією, яка могла б наступити, якщо б «потерпілий» мовчав. Однак жорстоке поводження за жодних обставин не може виправдовуватись, оскільки суперечить вимогам моральності. Більше того, якщо б існували такі винятки із правил, то, мабуть, чи не в кожній другій справі, де мало місце жорстоке поводження, посадові особи органів державної влади знаходили виправдання своїм діям і «приписували» такий випадок до тих, що є винятковими.

Передусім розгляду потребує семантичний зміст поняття «катування», яке трактується як тортури, мучення, мордування, завдання тяжких фізичних мук, сильне биття [7, с.107-108]. Прийнято виділяти два його різновиди: фізичне та психічне [8, с.230]. При цьому поняття фізичного катування охоплює діяння, що полягають у систематичному битті, заподіянні болю з використанням електричного струму, позбавленні можливості задовольнити фізіологічні потреби, занурення у воду з головою, удушення тощо [9, с.50; 10, с.121]. Як приклад заподіяння фізичних страждань можна навести справу «Ірландія проти Великої Британії», у якій вказується про наступні їх прояви: стояння біля стіни (примушування стояти протягом тривалого часу на пальцях ніг); покриття голови (одягання на голови мішків); шумовий вплив (вплив на потерпілих голосних і шиплячих звуків); позбавлення сну; позбавлення їжі та води. У свою чергу, психічні катування полягають у приниженні людської гідності, виснаженні, погрозі щодо застосування катувань чи погрозі вбивства близьких осіб, примусовому спостереженні за катуванням інших осіб тощо [10, с.121122].

У той же час відповідно до ч. 1 ст.127 КК України законодавець виділяє фізичне та моральне страждання. Така позиція законодавця є правильною, оскільки очевидно, що психічні страждання пов'язані 3 розладами психіки, а тому така особа потребує спеціалізованого лікування. 3 огляду на це видається більш правильно говорити про моральні страждання, які власне полягають у пережитих почуттях зневаги, приниження, відчуття власної неповноцінності тощо. Однак не можна виключати випадків, коли катуванням спричиняються психічні страждання. Наприклад, після того, як на очах у матері згвалтували іiі доньку, вона почала страждати на психічні розлади. Такі випадки повинні враховуватись судом як тяжкі наслідки, завдані злочином, а саме як обставина, що обтяжує покарання.

Навіть поверхневий аналіз диспозиції ст.127 КК України засвідчує про її недосконалість. Так, із формулювання «заподіяння сильного фізичного болю або фізичного чи морального страждання шляхом нанесення побоїв, мучення або інших насильницьких дій» випливає, що катування може вчинятися лише активним способом. Тобто законодавець виключає можливість заподіяння 
особі фізичних чи моральних страждань шляхом бездіяльності. Однак такі випадки не виключені. Загальновідомо, що поняття мучення розглядається як позбавлення людини чи тварини їжі, пиття, сну тощо. Тобто вчиняється шляхом бездіяльності. 3 огляду на це у диспозиції ст.127 КК України слід вказати про «інші насильницькі діяння», а не «інші насильницькі дії».

Виходячи з аналізу ч.1 ст.127 КК України, законодавець ставить на «однин рівень» фізичні та моральні страждання. Така позиція законотворця є справедливою, оскільки ці поняття перебувають у нерозривному зв'язку. Зокрема, у переважній більшості випадків, коли особі заподіюють фізичний біль, то вона також зазнає і моральних страждань. Не виключені випадки, коли моральні страждання є більш нестерпними для потерпілої (потерпілого), аніж фізичні (скажімо, примушування собі викопати яму чи згвалтування когось із рідних на очах). 3 цього приводу ᄉ.I. Скрекля справедливо зауважує, що довгострокові моральні страждання після катування нерідко перебільшують фізичні - почуття страху, незахищеності, невпевненості в особистій безпеці, оскільки больові відчуття залишаються в пам'яті доволі довше, ніж зникають на тілі сліди від насильницьких дій [2, с.91].

Судовій практиці України відомо чимало випадків притягнення до кримінальної відповідальності за спричинення катуванням як фізичних, так і моральних страждань. Як приклад, слід навести вирок Брусилівського районного суду Житомирської області від 12 березня 2014 р. Злочин було вчинено за наступних обставин. Так, 4 жовтня 2013 року, С. повернувся додому, перебуваючи у стані алкогольного сп'яніння, за місцем проживання, протягом тривалого проміжку часу умисно катував свою матір Ю., яка $є$ особою похилого віку. А саме звинувачував ії у всіх своїх невдачах та умисно заподіював сильне душевне страждання, яке проявилося в жорстокому та нелюдському відношенні, та сильного фізичного болю, шляхом нанесення побоїв, що виразилось у тому, що він наніс їй численні удари долонею руки по обличчю, декілька ударів рукою по верхніх та нижніх кінцівках, спричинивши, згідно 3 висновком експерта тілесні ушкодження у вигляді обширних синців на обличчі, перелом кісток спинки носу, обширних синців на обох верхніх кінцівках, синців на обох нижніх кінцівках, які за ступенем тяжкості відносяться до легких тілесних ушкоджень 3 короткочасним розладом здоров'я. Злочинні дії обвинуваченого супроводжувались примусом чинити дії, що суперечать ії волі, що виразилось у тому, що С. примушував свою матір ставати на коліна та цілувати його взуття, що принижувало ії гідність та спричинило потерпілій моральні страждання, обіцяючи при цьому припинити її бити, якщо вона виконає зазначені дії. Дії С. отримали кримінально-правову оцінку за ст. 127 «Катування» та ч.1 ст.122 «Умисне середньої тяжкості тілесне ушкодження» [11].

Іншим прикладом, коли потерпілій особі було заподіяно фізичне і моральне страждання шляхом катування, слугує вирок Залізничного районного суду м. Аьвова від 13 квітня 2017 р. Так, 9 вересня 2014 року обвинувачений, перебуваючи у квартирі 3 мотивів помсти, шляхом вчинення насильства обмежив Ю. у вільному пересуванні, зв'язавши руки та ноги останньої за допомогою розірваного простирадла та пластикового хомута, із заподіянням потерпілій фізичних та моральних страждань, які полягали в систематичному нанесенні останній ударів рукою по обличчю та таким чином незаконно позбавив волі, тримаючи потерпілу в квартирі проти ії волі, де вона більше не бажала перебувати.

Крім того, обвинувачений, зважаючи на те, що Ю. була зв'язаною та лише в футболці, оскільки попередньо порвав на ній білизну, не могла чинити опір, користуючись іiї безпорадним станом та погрожуючи фізичною розправою за допомогою ножа, бажаючи зломити ії фізичний та моральний опір, з метою залякування та покарання за те, що потерпіла, на його думку, була причиною сварки та розірвання стосунків 3 його дружиною, умисно заподіяв сильний фізичний біль та моральні страждання шляхом нанесення побоїв, спробами удушення, насильним заливанням алкоголю, залякуючи потерпілу згвалтуванням [12]. 


\section{Кримінальне право, кримінальний процес та криміналістика}

\section{Висновки}

Таким чином, питання боротьби із проявами катування перебувають під посиленою увагою міжнародних організацій та водночас потребують належної законодавчої регламентації. А тому проблема протидії кримінально-правовими засобами катуванню i надалі залишатиметься актуальним як для теорії, так і практики застосування.

\section{Література}

1. Ахтирська Н.М., Касько В.В., Маланчук Б.А., Мелікян А., Пошва Б.М., Фулей Т.І., Шукліна Н.Г. Застосування в Україні європейських стандартів протидії жорстокому поводженню і безкарності: науково-практичний посібник для суддів / За заг. ред. проф. Маляренка В.Т. K.: «K.I.C», 2011. 320 с.

2. Скрекля Л.I. Жорстокість як наскрізне кримінально-правове поняття: дис. канд.. юрид. наук. Спец.: 12.00.08 - кримінальне право та кримінологія; кримінально-виконавче право / Аьвівський державний університет внутрішніх справ. 2014 р. 246 с.

3. Конвенція проти катувань та інших жорстоких, нелюдських або таких, що принижують гідність, видів поводження і покарання. Ухвалена Генеральною Асамблеєю ООН 10 грудня 1974 р. Ратифікована Указом Президії Верховної Ради УРСР № 3484XI від 26 січня 1987 р. [Електронний ресурс]. - Режим доступу: http://www.igfm.org. $\underline{\text { ua/dokumenti/konvents-ya-proti-katuvan-ta- }}$ nshikh-zhorstokikh-nelyudskikh-abo-takikhshcho-prinizhuyut-g

4. Сванідзе Е. Боротьба з жорстоким поводженням і безкарністю: Права затриманих і обов'язки працівників правоохоронних органів / К.: К.І.С., 2009. - 40 с.

5. Аксой проти Туреччини від 18 грудня 1996 р. Справа №100/1995/606/694, Рада Европи: Европейський суд 3 прав людини, 18 грудня 1996 р. URL: https://precedent. in.ua/2016/04/08/aksoj-protyv-turtsyy/

6. Право на жизнь, запрет пыток и бесчеловечного или унижающего достоинство обращения или наказания: европейские стандарты, российское законодательство и правоприменительная практика / под общ. ред. С. И. Беляева. - Екатеринбург: Изд-во Урал. ун-та, 2005. 244 с.

Право.иа № 4, 2021
The article discusses the issues of national and international legal standards of combating torture. It is stated that the prohibition of rolling, non-local and such that demerits, behavior and punishment, it is an imperative norm of international law, which is imported into national legislation and reflects one of the key values of a legal and democratic state.

A person is suffering from physical and/or moral suffering. It is obvious that mental suffering is connected with disorders of psyche, and therefore such person needs specialized treatment. Given this, it seems more correct to speak about moral suffering, which actually lie in the feelings of neglect, humiliation, feelings of own inferiority, etc. At the same time, it is impossible to exclude cases when torture causes mental suffering. Such cases should be taken into account by the court as serious consequences of the crime, namely, the circumstance that burdens the punishment. The issue of combating the rolling stock is under the increased attention of international organizations and at the same time requires proper legislative regulation.

Key words: torture, rule of law, human rights, international legal standards for the protection of human rights, application of the practice of the European Court of Human Rights.

7. Большая советская энциклопедия / под ред. О.Ю. Шмидта. - М., 1937. Т.30. $703 \mathrm{c}$.

8. Новий тлумачний словник сучасної української мови: 42000 слів / за ред. Л.І. Андріївського. В 4 т. - К.: АКОНІТ, 1999. Т.3. 928 с.

9. Права людини у діяльності міліції: посібник 3 активних методів навчання / кол. авт.;за заг. ред. чл-кор. АПрН України, д-ра юрид. наук, проф. О. Н. Ярмиша.-Х.: Видво Харк. нац. ун-ту внутр. справ. 2006. 136 с.

10. Булда Д. Деякі аспекти кримінальної відповідальності за катування. Право Украӥни. № 7. 2005. С. 120-123.

11. Вирок Брусилівського районного суду Житомирської області від 12 березня 2014 р. Справа №275/993/13-к https://reyestr. court.gov.ua/Review/38020511

12. Вирок Залізничного районного суду м.Львова від 13 квітня 2017 р. URL: https:// reyestr.court.gov.ua/Review/65977227 